\title{
Macropotrema pertinax gen. et sp. nov. (Digenea : Paramphistomidae) from a wallaby, Macropus agilis, in northern Australia, and associated pathology
}

\author{
par D. BLAIR *, I. BEVERIDGE ** and R. SPEARE *** \\ *Department of Parasitology, University of Queensland, St. Lucia, Qld. 4067 Australia. \\ *" Institute of Medical and Veterinary Science, Adelaide, S.A. 5000 Australia. \\ ***Department of Tropical Veterinary Science, James Cook University of North Queensland, \\ Townsville, Qld. 4811 Australia.
}

\section{Summary}

Macropotrema pertinax gen. et sp. nov. (Digenea : Paramphistomidae) is described from the caecum of the macropodid marsupial Macropus agilis (Gould, 1842) from northern Australia. The new genus is characterised as follows: ventro-terminal acetabulum bearing many papillae; oral sucker with constriction and paired diverticula ; œsophagus with muscular bulb ; cirrus sac and genital sucker absent ; testes symmetrical, unlobed, preovarian ; Laurer's canal opening anterior to excretory pore. The genus is placed in the subfamily Pseudodiscinae Näsmark, 1937. At the point where the worm attaches to the caecal wall of the host, the entire mucosa is destroyed and there is an inflammatory cell infiltration in the intact mucosa surrounding the attachment site.

\section{Résumé.}

Description de Macropotrema pertinax n. gen. n. sp. (Digenea, Paramphistomidae) parasite du caccum de Macropus agilis (Gould, 1842) (Marsupialia, Macropodidae) du Nord de l'Australie.

Le nouveau genre présente les caractères suivants : acetabulum ventro-terminal orné de nombreuses papilles; ventouse orale pourvue d'une constriction et de deux diverticules; œsophage muni d'un bulbe musculaire; poche du cirre et ventouse génitale absentes; testicules symétriques, non lobés, préovariens; ouverture du canal de Laurer en avant du pore excréteur. Le genre est placé dans la sous-famille des Pseudodiscinae Näsmark, 1937.

La muqueuse de la paroi du cæcum de l'hôte est entièrement détruite au point de fixation du ver et autour de ce point s'observe dans la muqueuse intacte une infiltration cellulaire inflammatoire.

Accepté le 23 août 1979. 
Very few digeneans have been reported from macropodid marsupials. Apart from the ubiquitous liver fluke Fasciola hepatica L. in macropodids in southern Australia (Mackerras, 1958), the only digenean known is the paramphistome Gemellicotyle wallabicola Prudhoe, 1975 reported from Macropus agilis (Gould, 1842) (= Wallabia agilis) from western Papua (Prudhoe, 1975). During a survey of the helminth parasites of Macropus agilis in northern Australia, specimens of Gemellicotyle wallabicola were recovered from the stomachs of three out of 41 wallabies examined. Parasitised animals came from Ingham and a locality on Cape York Peninsula (see below). Another paramphistomid was recovered from the caeca of five wallabies. The authors consider that this worm represents a new genus and species, and the name Macropotrema pertinax is proposed for it.

\section{Materials and methods}

Wallabies infected with Macropotrema were obtained from Yabulu (20 km north of Townsville), from Ingham, from Stone's Crossing on the Wenlock River, Cape York Peninsula, all in north Queensland, and from Darwin in the Northern Territory. Specimens from Yabulu and Ingham were picked from the caecal contents of freshly killed wallabies, washed in $0,9 \%$ saline, and fixed in hot $70 \%$ alcohol. The caeca of wallabies shot on Cape York Peninsula were opened soon after death and immersed in $10 \%$ buffered formalin. On return to the laboratory the caecal contents were washed and sieved. Flukes recovered were stored in $70 \%$ alcohol. Four specimens from Yabulu and two still attached to the caecal mucosa of wallabies collected on Cape York Peninsula were embedded in paraffin and serially sectioned either in the sagittal or frontal planes. The sections were $7 \mu \mathrm{m}$ thick and were stained with haematoxylin and eosin. Two whole mounts were made of worms from Ingham. These were stained with Gower's carmine, carefully destained with $1 \%$ $\mathrm{HCI}$ in $70 \%$ alcohol, dehydrated, cleared in methyl benzoate and examined in the clearing agent. Dimensions throughout this paper are given in $\mathrm{mm}$ unless otherwise stated.

Attempts were made to work out the arrangement of circular muscles in the acetabulum, and of all muscles in the oral sucker, following the terminology of Näsmark (1937). Repeatable counts of muscles in the acetabulum could not be made, even when one observer examined a single section on several occasions. As a result, the numbers given below are very approximate.

\section{Macropotrema pertinax gen. et sp. nov.}

\section{Type Material :}

Holotype, consisting of serial sections, Yabulu, Queensland, 20-viii-1978, collector : I. Beveridge. In South Australian Museum, Adelaide, No. V1831. Five paratypes (serial sections of one specimen, four whole specimens in spirit) (location, date and collector as for holotype), in South Australian Museum, No. V1832-V1836. 
Three paratypes (whole specimens) (location, date and collector as for holotype), in Australian Helminth Collection (formerly University of Adelaide Zoology Department Helminth Collection) currently housed in South Australian Museum.

Two paratypes (whole specimens) (location, date and collector as for holotype), in British Museum (Natural History), Nos 1979.3.15.11-12. Two paratypes (whole specimens) (location, date and collector as for holotype), in United States National Museum Helminth Collection No. 75137.

Host : Macropus agilis (Gould, 1842) (Marsupialia : Macropodidae).

Location in Host : Caecum.

\section{Other Material examined :}

21 specimens, Ingham, Queensland, 16.x.1978, collector : R. Speare. 15 specimens, Stone's Crossing, Wenlock River, Cape York Peninsula, Queensland, 24.ix.1978, collector : I. Beveridge. One specimen, Darwin, Northern Territory, 22.xi.1975, collector: J. Hills. Etymology of Name:

Generic name compounded from name of host genus, Macropus, and trema, Greek for an aperture or opening. Specific name is Latin adjective meaning " that clings firmly ».

\section{Generic Definition.}

Paramphistomidae; Pseudodiscinae : medium to large-sized worms conical in shape. Acetabulum very large, postero-ventrally directed and bearing numerous papillae on its surface. Oral sucker constricted behind middle, bearing paired oral diverticula. Oesophagus with muscular bulb. Intestinal caeca lateral, extending more-or-less directly to acetabular region. Testes large, symmetrical, simple, rounded to triangular in ventral view, post-equatorial. Male terminal genitalia consisting of sperm duct dilated to form seminal vesicle, pars musculosa, cavernous and ciliated pars prostatica, and ejaculatory duct emerging on small genital papilla. Genital sucker and cirrus sac absent. Ovary to left of midline, post-testicular. Laurer's canal anterior to excretory vesicle and pore. Uterus greatly coiled, intercaecal. Metraterm uniting with ejaculatory duct at genital pore. Vitellaria in lateral fields, from anterior to level of oesophageal bulb to ends of caeca, ventro-lateral to caeca. Excretory vesicle on antero-dorsal side of acetabulum, running postero-dorsal to mid-dorsal excretory pore. Parasitic in macropodid marsupials.

\section{Description.}

Body: Pl. I, A-E.

The fluke is conical in shape and measures 4.0-5.0 (4.6 mean of ten paratypes) in length by 2.0-2.5 (2.4) in maximum width which occurs in the region of the acetabulum. The body is convex dorsally, flattened ventrally and the surface lacks spines.

\section{Acetabulum :}

The acetabulum has an internal diameter of 1.9 and its openings is directed postero-ventrally. Its surface is covered with numerous small spherical projections 0.04 0.1 in diameter. The tegument covering the projections is thinner than that covering 

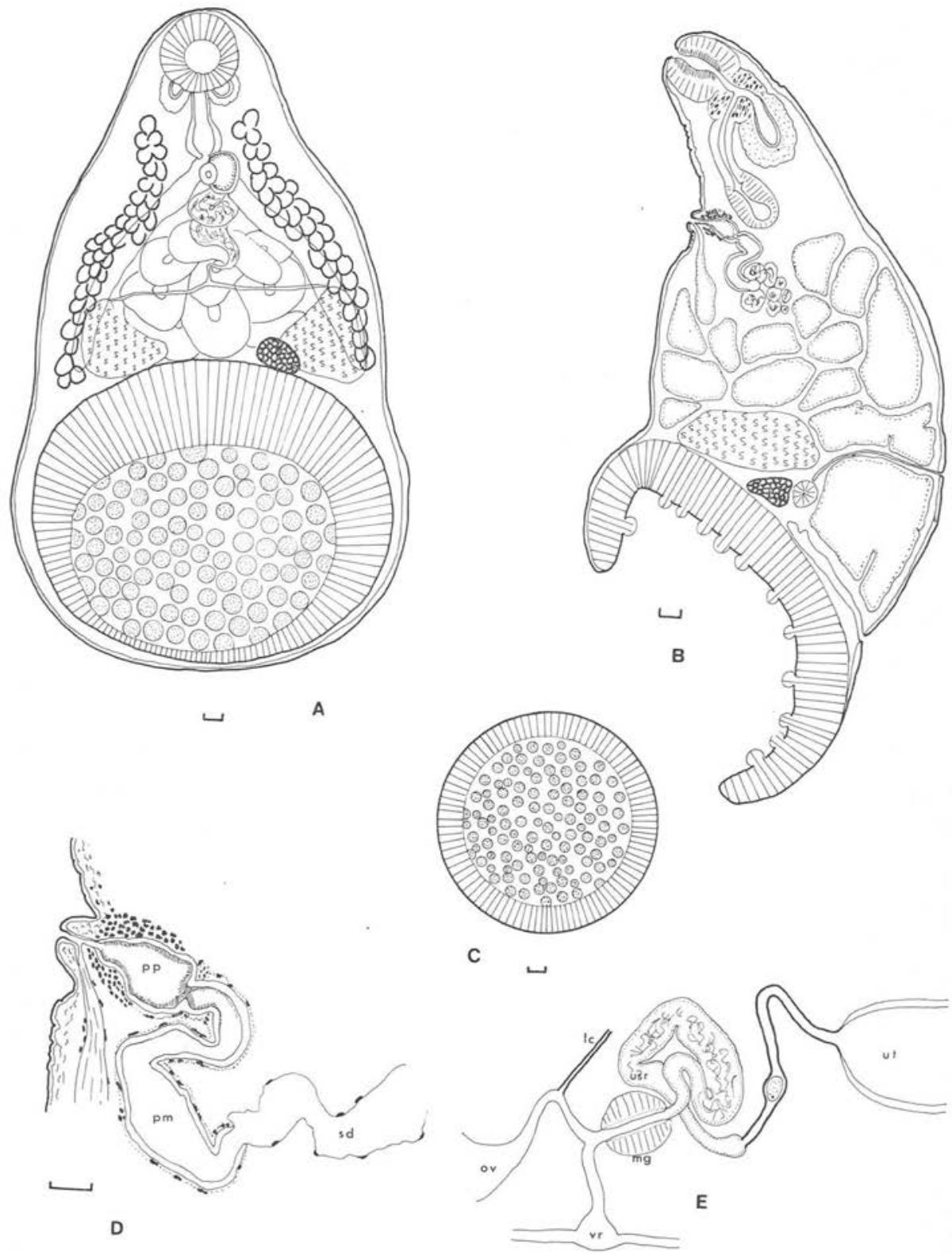

Plate I. - Macropotrema pertinax gen. et sp. nov.

$A$, ventral view, based on a whole mount and serial sections; $B$, composite median sagittal section $C$, view directly into opening of acetabulum; $D$, genital papilla and distal extremities of genital ducts; $E$, schematic representation of female genital complex. Scale lines : $0.1 \mathrm{~mm}$.

lc, Laurer's canal; mg, Mehlis' gland; ov, oviduct; pm, pars musculosa; pp, pars prostatica; sd, sperm duct dilated to form seminal vesicle ; usr, uterine seminal receptacle ; ut, uterus ; vr, vitelline reservoir. 
the remainder of the acetabulum and the sub-tegumental musculature is absent in the projections. The projections are composed of bundles of radial muscle fibres which extend into the base of each projection parallel to one another, then radiate to insert on the outer wall. There are few cell nuclei within the projections. Cell nuclei are disposed in an irregular band in the body of the acetabulum towards the distal margin.

Within the acetabulum there are approximately 50 circular muscle bundles in the dorsal interior layer and approximately 40 in the dorsal external layer. The ventral interior layer consists of about 60 bundles and the ventral external layer of about 30 bundles.

\section{Digestive System :}

The oral sucker measures 0.47 by 0.50 in sagittal section and is divided into two regions by a contriction towards its proximal end. The oral sucker appears to lack interior circular muscles. An inconspicuous band of interior longitudinal muscle lies interior to the middle circular muscle layer. The latter consists of quite well developed units. Neither of these muscle layers extends proximally beyond the constriction in the sucker. Radial muscles are most apparent towards the inferior of the sucker. External longitudinal muscles are not greatly developed. An anterior sphincter of strong circular fibres is present, but a lip sphincter, posterior sphincter and basal circular layer are all absent. Two oral diverticula are given off from the proximal end of the oral sucker. The diverticula are symmetrical on each side of the oesophagus. They are lined with tegument and are surrounded by a thick layer of pale coloured cells with foamy eosinophilic cytoplasm. The eosophagus is 0.5 long and has a thick muscular wall. It leads into a muscular bulb measuring 0.29 by 0.20 and situated dorsal and slightly anterior to the genital opening. The intestinal caeca emerge from the oesophageal bulb and run along the sides of the body, dorso-medial to the vitellaria, almost to the level of the acetabulum.

\section{Genital System :}

The testes are post-equatorial, symmetrical, ventro-medial to the ends of the caeca and vitellaria, and rounded to broadly triangular in ventral view. They are not lobed, and measure $0.85-0.93$ in length by $0.73-0.78$ in width by 0.89 in the dorso-ventral plane. A narrow sperm duct arises from the anterior of each testis and runs towards the midline. Here the two ducts unite to form a common duct which coils anteriorly. Initially the wall of this duct is thin, lacking muscular components, and the duct is distended with sperm. Distally the wall of the duct becomes muscular. This region is the pars musculosa which coils anteriorly and ventrally until it reaches the cavernous pars prostatica. The junction between these two regions is marked by a sphincter-like constriction of the duct wall and by tufts of long cilia which are most pronounced within the basal portion of the pars prostatica. The pars prostatica is a large chamber, measuring 0.13 by 0.14 in sagittal sections, with muscular walls and lined with cilia. It is surrounded by a thick layer of glandular cells, particularly towards its distal end. There is no cirrus sac. A short ejaculatory duct leaves the pars prostatica and traverses the small genital papilla to emerge at the genital 
pore which is mid-ventral in the anterior half of the body, dividing the body in a ratio of $1: 2$. The genital papilla is surrounded by a shallow depression of the body surface which could be termed a genital atrium. In sagittal sections, an increase in the density of cell nuclei may be seen in this area, but there is no clear evidence of a muscular sphincter either around the genital pore or around the shallow genital atrium. There is no genital sucker.

The ovary, which measures 0.22 in length, 0.32 in width and 0.19 in the dorso-ventral plane, lies to the left of the mid-line posterior to the testes and immediately anterior to the acetabulum. Mehlis' gland lies to one side, slightly dorsal to the ovary, and measures 0.22 by 0.24 by 0.19 . The oviduct arises from the dorsal side of the ovary and coils anteriorly to be joined by Laurer's canal. The latter is a narrow, thick-walled duct which runs towards the dorsal surface of the body. Its entire course to its mid-dorsal opening could be traced in sections of three specimens. In two, the opening was located well anterior to the excretory pore, but in the third it was located immediately anterior to this pore. At no point does Laurer's canal cross the excretory vesicle. After joining Laurer's canal, the oviduct fuses with the common vitelline duct, then passes into Mehlis' gland. The vitellaria lie ventro-lateral to the intestinal caeca and consist of follicles in a field extending down each side of the body from anterior to the level of the oesophageal bulb to the tips of the caeca. The junction of the single vitelline duct from each side to form the common vitelline duct occurs in the mid-line, postero-dorsal to the ovary, and may be marked by a swelling of the duct. On emerging from Melhis' gland, the female duct forms a much coiled region specialised as a uterine seminal receptacle. This is lined with a ciliated cuboidal epithelium and filled with sperm. Shelled eggs may also be present here. Connecting the uterine seminal receptacle with the remainder of the uterus is a narrow duct with muscular walls, capable of considerable distension when an egg is present in the lumen. This duct opens into the uterus proper, which is greatly coiled and lies in the area between the intestinal caeca. The metraterm is rather short, muscular, and follows an indirect course in the ventral mid-line anterior to the testes. The distal end of the metraterm merges with the ejaculatory duct close to the tip of the genital papilla. The eggs are operculate and measure $0.133-0.144$ ( 0.139 , mean of 30 measurements) by $0.077-0.083(0.08)$. The operculum is 0.006-0.009 (0.007) in height and 0.025-0.031 (0.03) in diameter.

\section{Excretory System :}

The excretory vesicle lies immediately antero-dorsal to the acetabulum and runs posterodorsally to its opening in the dorsal midline.

\section{Associated Pathology :}

Macropotrema pertinax is firmly attached to the caecal mucosa and can be removed only with some difficulty. When removed, a circular defect is present in the mucosa, of the same diameter as the acetabulum. Histological examination shows that at the site of attachment, the mucosa has been entirely destroyed and only a very thin layer of squamous cells covers the submucosa. The mucosa adjacent to the site of attachment is of reduced height when compared with non-infected animals, and there is infiltration by masses of mononuclear cells. 


\section{Discussion}

Näsmark (1937) divided the Paramphistomidae into subfamilies on the basis of the structure and musculature of the acetabulum and oral sucker (= "pharynx » of Näsmark). The present authors have attempted to interpret the arrangement of musculature in Macropotrema according to the methods of Näsmark. In the case of the acetabulum, only approximate numbers are given in the description above. As a result, comparison with other genera on this basis was impossible. Interpretation of the oral sucker musculature was somewhat easier. The oral sucker of Macropotrema falls within the group IIA of Näsmark, that is, it possesses a pair of oral diverticula. Näsmark placed four genera in this group, each in a separate subgroup. Macropotrema cannot be placed with certainty in any of these four subgroups. This is not surprising as it differs from each of the four genera in several respects other than oral sucker musculature. In the light of these considerations, the present authors prefer to place little importance on the oral sucker musculature as a definitive means for distinguishing between subfamilies.

Although Yamaguti (1971) largely retained the system of Näsmark, he employed a far wider range of features to identify subfamilies. According to this system, Macropotrema pertinax must be placed in the subfamily Pseudodiscinae Näsmark, 1937. The combination of characters which lead to this placing are as follows : body form; ventro-terminal acetabulum; oral sucker with constriction and paired oral diverticula; presence of an oesophageal bulb; absence of cirrus sac and genital sucker; well developed pars musculosa; symmetrical preovarian testes; Laurer's canal opening anterior to excretory pore. Yamaguti (1971) recognised three genera within the Pseudodiscinae. These are Pseudodiscus Sonsino, 1895, Hawkesius Stiles and Goldberger, 1910 and Choerocotyle Baer, 1959. While closely fitting the subfamily diagnosis, Macropotrema differs markedly from each of these three genera. It differs from all three in its possession of papillae on the acetabulum and by the size of the acetabulum itself. It can further be differentiated from Pseudodiscus as the latter lacks on eosophageal bulb and has small multilobed testes. Hawkesius and Choerocotyle both differ from Macropotrema in possessing testes in tandem. In Choerocotyle the oral sucker is not constricted.

The relationship between Macropotrema and Gemellicotyle, the other paramphistome from a wallaby, is not very clear. The reproductive systems are similar in both. Neither possesses a cirrus sac nor a genital sucker. Both possess a large sac-like pars prostatica lined with cilia, a uterine seminal receptacle, and symmetrical pre-ovarian testes. In Gemellicotyle however, the testes are lobed. This genus may be further distinguished from Macropotrema by the absence of paired oral diverticula and of an oesophageal bulb. Instead of numerous small papillae on the acetabulum, Gemellicotyle possesses a single large central " adhesive organ » (Prudhoe, 1975) on the acetabulum. A further difference between the two genera lies in their pathogenic action. No lesions were found in the stomachs of Macropus agilis infected with Gemellicotyle wallabicola, whereas Macropotrema pertinax leaves distinct circular lesions at the site of its attachment in the caecum. Prudhoe (1975) placed Gemellicotyle in the subfamily Paramphistominae Fischoeder, 1901. 


\section{References}

Mackerras M. J., 1958 : Catalogue of Australian mammals and their recorded internal parasites. Part 1. Monotremes and Marsupials. Proc. Linn. Soc. N.S.W., 83, 101-125.

Näsmark K.E., 1937 : A revision of the trematode family Paramphistomidae. Zool. Bidr. Upps., 16, 301-566.

Prudhoe S., 1975 : A new genus of paramphistome trematode from a wallaby. Dr. B.S. Chauhan Comm. Vol., 63-68.

Yamaguti S., 1971 : Synopsis of digenetic trematodes of vertebrates. Vol. I and II, Keigaku Publ. Co. Tokyo, 1074 p. 